\title{
Analysis of the Need for Stock Market in Ethiopia
}

\author{
Haileberhan Zena ${ }^{1}$ \\ ${ }^{1}$ Deputy CEO in Federal Housing Corporation, Ethiopia \\ Correspondence: Haileberhan Zena, Deputy CEO in Federal Housing Corporation, Ethiopia. Tel: \\ 251-977-955-859. E-mail: hailezena@gmail.com or haileberhan_zena@yahoo.com \\ Received: December 8, 2020 \\ Accepted: January 30, 2021 \\ Online Published: January 31, 2021 \\ doi:10.5539/ijef.v13n2p84 \\ URL: https://doi.org/10.5539/ijef.v13n2p84
}

\begin{abstract}
Private sector participation and performance in the Ethiopian economy is weak. This is due to insufficient access of financial resources to the private sector. The credit market in the country has been overwhelmingly dominated by state-owned banks whose lending efforts have been dedicated to expanding public infrastructure projects and state owned enterprises as a matter of policy. The current government reform initiative by the name 'Home-grown Economic Reform' is expected to bring some adjustments in the financial system so that the private sector can have better choice for its long term investment needs with the introduction of market-based financial access. This study employed desk review of secondary data with content analysis of appropriate conceptual and empirical literature. Analysis of establishing stock market as a major alternative to bank based system is conducted using two models: business growth life cycle model and the financial structure model. The models are thought to explain the potential contribution of the development of equity market as a complement to the credit market in the financial structure of the country given the early stage of growth of the economy. The findings shown that establishing and developing stock market is strongly recommended to complement bank services and as an alternative financial access system both to investors and entrepreneurs. Issues to be considered in the process of establishing a stock market are provided as a way forward.
\end{abstract}

Keywords: economic growth, finance, stock market

\section{Introduction}

\subsection{Background}

Ethiopian economy has been growing at a faster rate for more than the last fifteen years. This impressive result has been delivered by the strategy that emphasized strong public investment. According to official statistics, Ethiopia's annual rate of economic growth averaged 10.3 percent over 2005/06-2015/16 (World Bank, Ethiopia Economic Update, 2018). In the Annual Report of the National Bank of Ethiopia (2018/19), the economic growth rates registered for 2017/18 and 2018/19 were 7.7 percent and 9 percent respectively which were lower than the targets for the respective years and 10 years average stated above by the World Bank. Nevertheless, the growth is accompanied by slow structural transformation with the contribution of the industrial sector to GDP being not more than $17 \%$ and the performance of the manufacturing sub-sector only $4 \%$ of GDP share, much lower than expected and envisaged in country's industrial sector policy (Foreword by Mekonnen Manyazewal, in Mulu Gebreeyesus et al., 2018).

The International Financial Corporation Report (2019) with a title, 'Creating Markets in Ethiopia' identified that access to credit and financing continued to be the major concern of the private sector as only 16.4 percent of this sector accessed credit from banks for its activities, compared with Kenya and Uganda, where private sector enjoyed about 41 and 21 percent access respectively. Base line survey on Main Features of Micro and Small Manufacturing Enterprises in Ethiopia by Mulu Gebreeyesus et al. (2018) also indicated that more than $70 \%$ of Micro and Small Enterprises had no access to credit from any of the potential sources; thus, they must rely on their own funds; and from those that had access two-thirds of them reported having loan access from Micro Finance Institutions, and only about 15\% from formal banks. The Doing Business 2019 ranking for Ethiopia also shows a gloomy situation on access to credit, putting the country on $175^{\text {th }}$ position out of 190 countries with only 15 points out of 100 and compare this point in the same ranking for Rwanda 95, Kenya 90 and regional average for Sub Saharan Africa 42 out of 100 (World Bank, Doing Business 2019).

Failure to timely address the challenges had resulted in serious macro-economic imbalances which called for the current government to introduce a reform named 'Home-grown Economic Reform' aiming at reducing 
expansionary fiscal policy which was undermining the contribution of the private sector and crowding out the private sector according to the State Minister, Ministry of Finance (Ethiopian News Agency, August 29/2019). This reform, in its financial system review in my view, should consider market-based financial resources access options as an alternative to bank based system so that the private sector can have better choice for its long term investment needs. The Ethiopian economy had experience to the stock market as one form of financial market, which was instituted during the Imperial Regime in 1965 known under the name of "Share Dealing Group" with focus in shares trading of the private investment community (Tiruneh Legesse, 2012). This share market was abolished in 1974 with a regime change to command economy and nationalization of private property. With the downfall of the command economic system in 1991, the country has experienced a number of economic policy and strategy changes, the reforms favoring market led economic development.

Many practitioners and academicians in the country have been raising the issue of establishing financial market, particularly, stock market as a missing ingredient in the economic reform steps taken so far. There were even initiatives by a group of entrepreneurs organized as the Ethiopian Share Dealing Group (ESDG) under the Addis Ababa Chamber of Commerce and Sectoral Associations (AACCSA) with the intention of forming similar share market to the former Addis Ababa Share Dealing Group of 1974 by developing rules and regulations as well as by-laws for the stock market (Ruediger Ruecker, Addis Ababa Chamber of Commerce and Sectoral Associations, 2011). Some writers, on other side, are hesitant about the benefits of establishing financial markets in Ethiopia. Recent newspaper article by Solomon Gizaw (Capital Newspaper, April 1, 2019) was of the opinion that given the present stage of its economic development and weak institutional infrastructures, Ethiopia could benefit more by using the bank-led financial model as its prime financial system rather than sharing the meager savings to both systems. This study intends to do some analysis and add views in the forthgoing discussion about the importance of introducing stock market as an option to serve long term investment needs of the private sector in Ethiopia.

\subsection{The Research Problem and Questions}

The Ethiopian economy has been growing at a faster rate for more than a decade. The transformation in the economic structure envisioned in the growth has been slow and the private sector participation expected to surge in the growth process has been weak. The major cause for the weak performance of the private sector is thought to be the financial resource allocation policy of the government which mainly functions with banks as intermediaries has been tending to favor the public investment and crowd out the private sector. The current government's reform initiative is believed to touch banks credit policy and inclusion of alternative financial market so that it can encourage greater and expanding private sector participation in the economy.

The research questions, therefore, will be:

1) What do the experiences of other countries, especially of less developed Sub Saharan Africa countries show in regards to the contribution of stock markets in economic growth?

2) Should we delay any further the establishment of the stock market?

3) What policy recommendations can we draw for the way forward?

\subsection{The Research Objective and Significance}

The objective of this research is to expand the financial access options to the private sector in the financial system of the country by analyzing the viability of establishing stock market in Ethiopia. As this research may produce policy recommendations which would contribute in expanding options of access to financial resources for the highly restrained private sector, the significance of research can be considered as high in the development of the financial system of the country.

The available research on the financial markets of Ethiopia largely focuses on the importance and ways of establishing a stock market and the research analysis on the actual contribution of the financial markets to growth of the country's economy is weak. This research being analytical on the potential contribution of a stock market in the economic growth of the country, its significance in the critical review of the financial system development policy would be great.

\subsection{Research Methodology}

As Ethiopia does not have active stock market so far, we do not have both primary and secondary data useful for the analysis of the contribution of stock markets to the growth of Ethiopian Economy. Hence, conducting a systematic review of conceptual and empirical literature in the field of financial markets through content analysis is used as a major methodology to draw conclusion and recommendations. Some secondary data (on trade 
license registry, Global Findex 2017 and Ease of doing business ranking for 2017 and 2019) were used for descriptive analysis.

\subsection{Limitations of the Research}

Except for the rudimentary primary share issues, government bonds and treasury bills issues and interbank money market, there is no secondary financial market in the country where financial securities are traded. Therefore, data for the analysis of financial market and growth nexus in the country is not available. This fact pushed this research work to depend on experiences and empirical research findings on other countries as proxy for Ethiopia, which can be taken as a major limitation of this research.

\section{Literature Review}

\subsection{Financial Systems Development and Economic Growth}

We can see that the importance of finance on the growth of an economy at macro level and corporate financial strategy on mobilizing financial resources for firms at micro level have attracted the attention of different economists and business development strategists. At the macro level, especially, the financial development-growth nexus witnessed debates of researchers beginning from Schumpeter (1912) who contended that efficient financial intermediation spurred technological progress by reallocating investment funds to those entrepreneurs with the best chances of successfully implementing innovative products, with a process he referred to as "creative destruction." On the other side, writers likeRobinson (1952) argue that financial system does not spur economic growth but financial development simply responds to developments in real sector. The debate is ongoing and has been revolving around two issues (Odunga \& Ayoyi, 2016). The first relates to whether development in the financial markets results in a faster economic growth, and the second issue is concerned with the ways how financial markets affect economic growth.

Odunga and Ayoyi (2016) further elaborate the theoretical analysis of the relationship between financial markets and economic growth broadly under four hypotheses. First, the conventional view of the supply-leading hypothesis which postulates that the direction of causality flows from financial development to economic growth. Efficient financial services result in a more efficient allocation of resources, a more rapid accumulation of physical and human capital, and faster technological innovation, thus inducing faster long-term economic growth (Goldsmith, 1969; Shaw, 1973; McKinnon, 1973; King \& Levine, 1993; Songul et al., 2009). Second, the demand-following hypothesis postulates that financial development follows economic growth as the development of the real economy induces increased demand for financial services, as a result of which the need for new financial markets and institutions arise to satisfy the increased demand for financial services (Robinson, 1952; Patrick, 1966; and Demetriades \& Hussein, 1996). Third, the bi-directional causality hypothesis, which is a combination of the supply-leading and demand following hypotheses. According to this hypothesis, financial services expansion and economic growth are mutually or bi-directionally causal (Greenwood \& Jovanovic, 1990; Saint-Paul, 1992; Berthelemy \& Varoudakis, 1996; Demetriades \& Hussein, 1996; Greenwood \& Smith, 1997; Blackburn \& Hung, 1998; and Harrison, Sussman \& Zeira, 1999). Fourth, the independent hypothesis that postulates financial deepening and economic growth are causally independent, which ignores the importance of finance and argues that financial deepening plays a very minor role in economic growth process (Lucas, 1988; Stern, 1989).

Since the beginning of the 1990s, a growing body of empirical work, including broad cross-country and panel studies, time series analyses, individual country case studies, and firm and industry level analyses, have provided evidences supporting the view that financial development is not just correlated with economic growth; it is actually one of its drivers (Augusto \& Sergio, 2007). A multi-country study by Levine and Zevros (1998), using data from 47 countries over nearly 20 years, concluded that stock market liquidity and banking development were strongly contributing to enhance the rate of economic growth. Levine (2005) also described that financial systems help in mobilizing and pooling savings, allocating capital, monitoring investments, facilitating risk diversification and management, and facilitating the exchange of goods and services. More recently, Levine, Loayza, and Beck (2000) have shown that financial sector development helps economic growth through more efficient resource allocation rather than through increases in the scale of investment or savings mobilization (as quoted in Ayyagari et al., 2012).

Banks and other financial institutions take the relatively small savings of large numbers of individuals, aggregate them together, and thus make funds available for larger-scale enterprises (Joseph, 1993). He further noted that a financial system functions in the assessment and identification of managers and projects with the potentials of yielding the highest returns. This observation presupposes the view that those who have funds are not necessarily those who are most capable of using the funds, and hence, financial systems perform an important role in 
transferring funds to those for whom the returns are the highest.

The three most important forms in which capital is provided for companies are equity, long-term loans, and short-term loans. The financial system of a country discharges these functions through either banks or financial markets (where stocks of companies and loan security markets are listed and traded (WEF, 2017)) or in combination of these depending on the specific situation of the country. As the focus of this research is on the importance of stock markets in driving economic growth, it is appropriate that the in-depth review of theoretical and empirical researches on this area is covered in greater detail.

To show theoretical links between stock markets and long-run growth, Levine (1991) and Valerie et al. (1995) derived models that show more liquid stock markets, where it is less expensive to trade shares of companies, and reduce the disincentives of investing in the long-duration projects because investors can easily sell their stake in the project if they need their savings before the project matures. High liquidity of stock markets, therefore, promotes investors participation in longer-run, higher-return projects that boost productivity and economic growth. Well-functioning capital markets help ensure the financial system's efficiency, stability, and risk management, preventing costly crises and helping channel savings toward investment that is essential for economic development and poverty reduction.

There also exists theoretical debate about whether greater stock liquidity actually encourages a shift to higher return projects that stimulate productivity growth. As more liquidity makes it easier to sell shares easily, some argue that more liquidity reduces the incentives of shareholders to undertake the costly task of monitoring managers (Andrei \& Robert, 1986; Amar, 1993, Stiglitz, 1985 \& 1993).

A multi-country study by Levine and Zevros (1998), using data on 47 countries over nearly 20 years (from 1976 through 1993) and measuring stock market development along various dimensions: aggregate stock market capitalization to GDP and the number of listed firms (size), domestic turnover and value traded (liquidity), integration with world capital markets, and the standard deviation of monthly stock returns (volatility) concluded that stock market liquidity and banking development were positively and robustly correlated with contemporaneous and future rates of economic growth. Granger causality test by Boubakari and Jin (2010) to find causality relationship between stock market and economic growth based on the time series data compiled from 5 Euronext countries (Belgium, France, Portugal, Netherlands and United Kingdom) for the period 1995 to 2008 showed a positive links between the stock market and economic growth for some countries for which the stock market is liquid and highly active; and whereas, the causality relationship is rejected for the countries in which the stock market is small and less liquid.

In many other researches, researchers similarly argued that there is a positive correlation between stock market development and economic growth: Atje and Jovanovic (1989) found also a significant impact of the level of stock market development along with banks on economic growth; Rajan and Zingales (1998) argued that stock market size is directly correlated with growth; Mauro (2000) concluded that stock market is a stable predetermining factor of economic growth in emerging economies (as captured in Boubakari \& Jin, 2010).

\subsection{The Importance of Financial Structure in Economic Growth}

Another important question that has attracted significant debate in the literature is whether the financial structure, that is the mix of financial markets and banks operating in the economy, matters (Augusto \& Sergio, 2007). The literature on the real effects of financial structures has broadly concluded that both markets and banks exert a positive effect on economic growth. To mention few of them captured in (Popov, 2017), Hsu, Tiang, and Xu (2014) using a large data set that includes 32 developed and emerging countries, with a fixed effects identification strategy to determine the economic mechanisms through which the development of equity markets and credit markets affects technological innovation, they found out that more high-tech industries and higher level of innovation were exhibited in countries with advanced level of development of stock markets. In a more recent empirical contribution, Demirg Kunt, Feyen, and Levine (2013) use a large cross-country sample and show that as countries develop economically, the association between an increase in economic output and an expansion in bank services gets less significant, and the relationship between an increase in economic growth and an expansion in securities market services becomes more important.

Capital markets provide competition and complement to bank finance, encouraging banks to increase their efficiency, and allowing households and firms to better manage risks associated with long-term investments (World Bank/IEG, The World Bank Group's Support to Capital Market Development, 2016).

\subsection{The Performance of Stock Markets in Africa}

According to Schiereck et al. (2018), there are 30 organized stock exchanges on the African continent where 
securities can be listed based on a survey on stock exchanges in Africa at the end of 2016. These exchanges represent the capital markets of 40 African nations or around 74\% of Africa's sovereign countries (with 2 stock exchanges formed by group of nations in Western and Central Africa), Africa's largest stock exchange in terms of market capitalization being the Johannesburg Stock Exchange (JSE) in South Africa with a market capitalization of around 1 trillion USD as of the end of the year 2013.

There are significant number of empirical works which support a positive relationship between stock market and economic growth in Africa. Emmanuel and King (2014) examined the effect of capital market development on economic growth in Ghana for the period 1991-2011, whose empirical result revealed a positive bi-directional relationship between economic growth and capital market development, with a stronger effect from capital market development to economic growth. The study by FANTESSI Amavi Agbélénko (2016) by employing General Moment Method (GMM) examined the relationship between stock market development and economic growth by selecting a sample of 11 African stock markets (in 6 countries) for the period 1995-2014. The findings of this study revealed that market capitalization and stock values traded had a negative and insignificant effect on economic growth in Africa. In addition, the results of this study showed that stock market turnover contributes positively to economic growth but it is statistically insignificant.

Rabi et al. (2015) investigated the impact of stock market development on economic growth in Nigeria for the period 1990-2010. The author employed the ordinary least square techniques and the results showed that both market capitalization and value traded ratio have a negative impact on economic growth in Nigeria, while turnover ratio indicated a strong positive effect. Alajekwu and Achugbu (2012) addressed the role of stock market on economic growth in Nigeria for the period 1994-2008. The findings of the study revealed nearly similar result with Rabi et al. (2015) that market capitalization and value traded ratio have a weak negative effect on economic growth in Nigeria while turnover ratio has a very strong positive impact on economic growth.

Ikikii and Nzomoi (2013) conducted a research to empirically establish whether the development of Nairobi Securities Exchange affected economic growth in Kenya using linear regression methods to analyze the quantitative effects of stock market development on economic growth with a quarterly time series data on gross domestic product, market capitalization and trade volume covering the years 2000 to mid-2011, a total of 46 observations. The study revealed stock market development in Kenya positively contributed to economic growth considering developments on market capitalization and trade volume in Kenya; and that stock market size, as measured by market capitalization, has a stronger influence on economic growth than stock market liquidity, may be due to market illiquidity.

\subsection{The Development of Stock Markets in East Africa Region and Ethiopia}

East Africa remains the fastest growing sub-region in Africa, with estimated growth of 5.6 percent in 2017, up from 4.9 percent in 2016 forecasting buoyant growth reaching 5.9 percent in 2018 and 6.1 percent in 2019 (African Development Bank, 2018; and Biau, 2018). Growth in capital markets in East African region, however, has not kept up with the pace of the growth of the economy. Whereas in Latin America and East Asia, economic growth over the past decades spurred impressive expansion in capital markets, growth in East Africa did not have similar impact as East Africa's capital-market development has been relatively slow (Biau, 2018; and Odunga \& Ayoyi, 2016).

The East African region has a relatively shallow capital market compared to some markets in Northern and Southern Africa. The East African market comprises the markets of Kenya, Tanzania, Uganda, Rwanda and Somalia where Kenya's capital market maintains a clear dominance in the Eastern region of the continent with a 52\% market capitalization, 18.945 billion USD out of the region's 36.418 billion USD (Dirk et al., 2018, Odunga \& Ayoyi, 2016).

Ethiopia had a short-lived stock market which was started during the Imperial Regime in the late 1950s and after the enactment of the Commercial Code Ethiopia in 1960, it was formally instituted in 1965 and abolished shortly in 1974 with the downfall of the Imperial Regime replaced by the military rule with a command economic policy (Tiruneh, 2012; Getachew, 2016). With the change of the command economic system in 1991, the country has experienced a number of economic policy and strategy reforms, favoring market led economic development. Since the reform started, a number of literatures have been produced, notably by scholars from academia and Addis Ababa Chamber of Commerce and Sectoral Association (AACCSA) towards reinstituting a stock in Ethiopia (Tiruneh, 2012; Abay, 2011; Ruecker, 2011; Abenet, 2018 on Fortune Vol. 19 No. 948).

The dominant hope of the writers was that reinstituting a stock market in Ethiopia would immensely contribute in the economic transformation of the country by encouraging the flourishing new business ideas, creativity, innovation and exerting market efficiency. It is also believed that the introduction of a stock market would 
enhance the privatization of public enterprises in the hands of the government by assuring transparency of the process, opening wider opportunities to individuals and private sector enterprises in the ownership of big businesses and assigning market value to the shares of the public enterprises (Abenet, 2018; Abdu, 2016).

Many of the writers are suggesting that regulatory reforms are required to start stock markets and develop and strengthen the country's capital markets in general in areas like updating commercial code, financial reporting and auditing standards (started and implementation ongoing), enacting laws mandating regulatory and stock exchange institutions (International Finance Corporation, 2019; Getachew, 2016; Tiruneh, 2012).

There is also an indication that some are wary of the introduction of stock markets in the country raising the problem of weak investor base and weak institutional infrastructure and that the meager savings in the economy should only be accessed through banks and not scattered in banks and stock markets (Solomon, 2019; Tiruneh, 2012).

\section{Anaysis of the Need for Stock Market in Ethiopia}

\subsection{Business Growth Life Cycle and Financing Strategy}

The growth of a business depends on a number of factors, one of which is availability of financial resources. The purpose of this analysis is to provide an alternative financing option for business growth, analyzing how each corporate entity or its sub-unit decides its funding sources at micro level, to give a better picture to generate a macro level policy options.

To describe the relationship between business growth and financing options a business growth 'Life Cycle' model, which describes business growth from start-up/launch to growth, then to maturity, then to decline and possible demise was used in depth in Bender and Ward (2009) to analyze corporate financial strategy. Based on this model, early-stage businesses are risky and thus, businesses at the launch stage should be financed with equity that is prepared to accept a high risk, such as venture capital. Jean (2006) also argue that debt financing is not an attractive alternative for the types of start-up companies, often in high-tech industries, as many such firms do not generate positive cash flows for quite a while and any short-term debt obligation could lead them into bankruptcy.

At the growth stage, the business is still risky as managing rapid growth is hard work and many companies fail to make the transition successfully, making debt finance not as a good idea, still requiring equity finance taken often from stock market. As the business gets stabilized and reaches maturity, its business risk reduces and so it should reduce its overall cost of capital by taking on cheap debt to replace the expensive equity. Once the business goes into decline, its riskiness (the volatility of expected results) is low and so the financial risk can increase and the company should borrow.

According to this model, each stage of business growth with associated business risk and corresponding suggested financing option is summarized in the following picture and table.

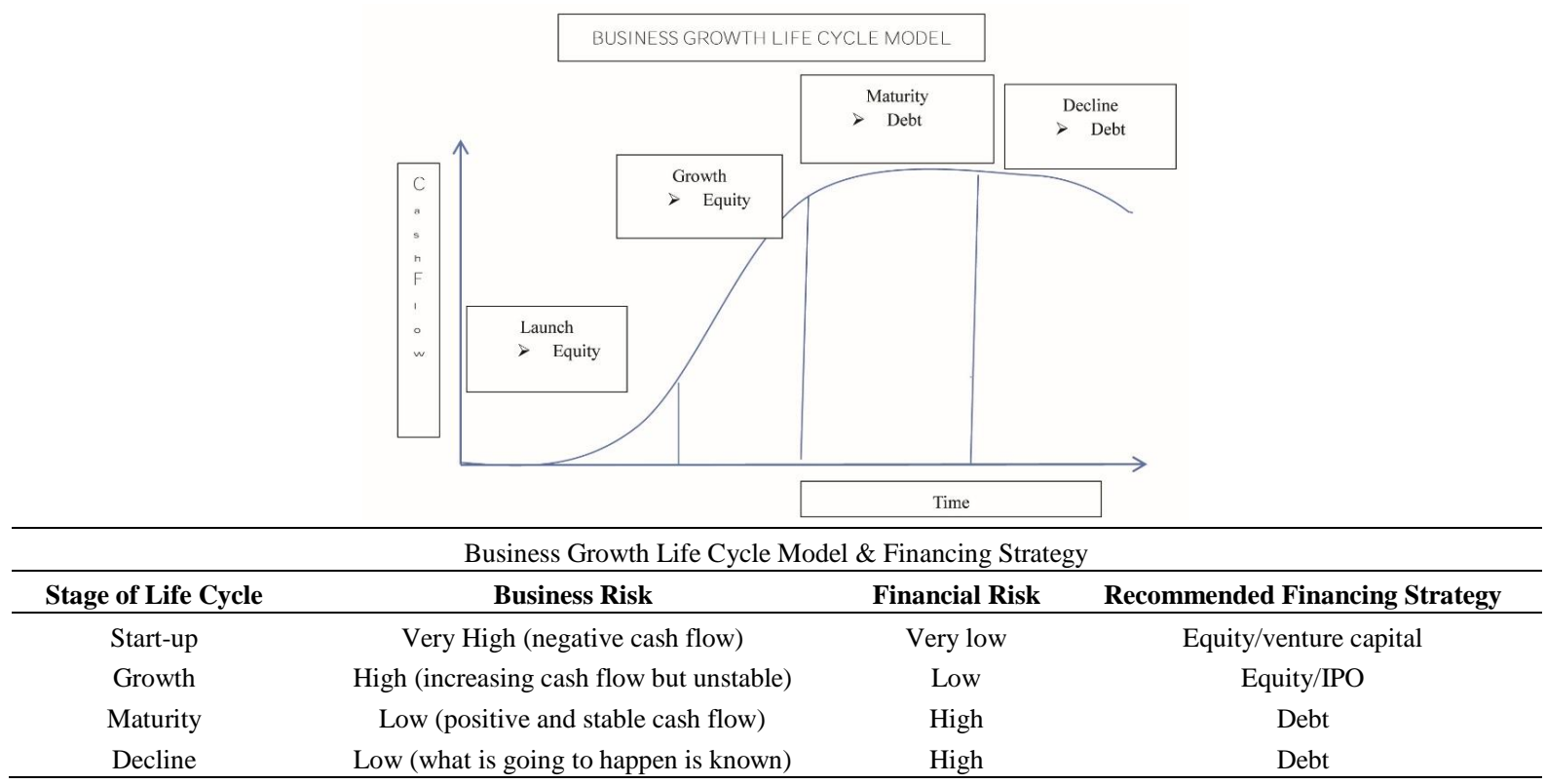

Adapted from Bender and Ward (2009). 
What does this mean in the context of the fast growing Ethiopian economy is the question we need to answer in this analysis. As stated earlier, the Ethiopian economy has been growing at a fast rate for more than the last fifteen years as a result of largely strong public investment in infrastructure and public services (WB Ethiopia Economic Update, 2018; NBE Annual Report, 2018/19; IFC, 2019). Though the economy growth rate maintained so far is commendable, some facts from the macroeconomic indicators create grave concerns. According to NBE Annual Report (2018/19), the annual average headline inflation galloping at 12.6 percent in 2018/19 though down from 14.6 percent in the previous year and the Ethiopian external sector particularly exports was performing poorly as the total merchandise exports showed a 6 percent contraction in the same year; which we can largely ascribe to the weaknesses in the domestic production capability and competitiveness.

As the Ethiopian economy is growing from a very lower base, smallholder agriculture and services are dominant sectors as a result of slow structural transformation in the economy (Admasu, 2017; IFC, 2019). The economy is also characterized by weak private sector performance due to insufficient access to financial resources as the credit market in the country has been overwhelmingly dominated by state-owned banks whose lending efforts have been dedicated to expanding public infrastructure projects and state owned enterprises as a matter of policy (Admasu, 2017; IFC, 2019). According to IFC (2019) report, the existing domestic financing model is inefficient and not market-based and that the recent reform efforts required developing and strengthening market-based financial system which need to accommodate more broad-based and competitive private sector participation.

According to the baseline survey report on the main features of micro and small enterprises in Ethiopia (Mulu Gebreeyesus et al, 2018), the micro and small enterprises sub-sector which we can take as the basis for the industrialization of the country, was dominated by young firms that had operated, on average, for about five years since establishment with about $23.8 \%$ of the sample micro and small enterprises had two or less years of operation in contrast with only $16.5 \%$ of them had been in business for more than a decade (about $60 \%$ had between 2 and 10 years). Taking the growth pattern of small and medium enterprises (SMEs) as an indication of the modern industrial and private sector development, we can categorize the Ethiopian economy as at early stage of growth based on the 'growth life cycle' model. The implication of having such young and less-established firms in the economy is that businesses are volatile with high rates of startups and terminations, depicting high level of business risk inherent at this stage of growth.

Based on the table above, adapted from Bender and Ward (2009), because of the high business risk during the startup and early growth stage, businesses are recommended to get financed through risk-free own finance or low risk equity finance from venture capitalists to keep the financial risk at lower level. Findings from the Ethiopian micro and small enterprises survey observed to be in agreement with this general proposition. The survey by Mulu Gebreeyesus et al. (2018) shows that the micro and small enterprises' credit access was very much limited as above 70\% Micro and Small Enterprises had no access to credit from any of the potential external sources; thus, they relied on their own funds. And that of the enterprises that had access to loans, two-third reported having loan access from micro finance institutions, while only about $15 \%$ from commercial banks indicating that formal banking has not been accessible by micro and small firms. This observation is consistent with the financing principle that proposes low risk equity finance to reduce the overall risk of business development during the startup and early growth stage where business risk is high.

This leads us to conclude that the Ethiopian government should look for developing ways of attracting equity finance to induce and sustain growth of new and existing businesses to generate more employment and expand the production of goods and services, which is in line with the economic reform agenda of the government. International Financial Corporation (2019) also recommends financial market development facilitating long-term finance that requires a more market-oriented approach promoting the efficient allocation of scarce financial resources and increases the participation of private financing.

\subsection{The Importance of Financial Structure and Stock Market Development}

Another important question for corporate financial strategy at micro level is whether the financial structure that is, the mix of financial markets and banks operating in the economy or the mix of equity and debt - matters (Torre \& Schmukler, 2007).

AS captured in (Jean, 2006) in their two articles in 1958 and 1961, Modigliani and Miller came up with a theory called 'M\&M theory' after their names, with the proposition that, under some conditions, the total value of the firm - that is, the value of all claims over the firm's income - is independent of the financial structure. According to this assertion, as long as the firm is able to fund opportunities that create value, it does not matter whether those opportunities are funded with equity or debt.

This view had attracted critics who claimed at least the tax savings due to the deductibility of interest payments 
to debt holders that added significant value to the firm and the likelihood of bankruptcy which increases financial distress causing the value of the firm to decline (Bandopadhyaya, Callahan, \& Shin, 2012). Bandopadhyaya, Callahan, and Shin (2012) detail different forms of 'trade-off' theories, as improvements to M\&M theory, whose underlining premise is that a firm would identify an optimal capital structure that it believes would balance the benefits of the tax shield against the costs of financial distress and that even though capital structure may diverge from a target due to factors including the accumulation of profits, investment expenditures, transaction costs, deliberate actions taken by managers and changes in market prices. In Bandopadhyaya, Callahan, and Shin (2012), the theory based on the target capital structure is also contrasted with an opposing theory called the pecking order theory; which suggests the choice of capital structure reflects the tendency of firms to prefer financing new projects with internal funds, issuing debt or equity motivated by management's view to the scrutiny of capital markets and the costs associated with information asymmetries.

Regarding the dominance in the structure, Torre and Schmukler (2007) pointed out that compared with capital markets banks may have some advantages in researching firms and monitoring managers, as banks with close ties to firms may be able to exert pressure for repayment and to monitor managers more effectively than atomistic markets. (Stiglitz, 1993) also remarked that a change in financial structure by increasing firm debt resulted in increase in firm value, which he partly attributed to the fact that with high debt, managers are forced to work hard.

On the other hand, regarding equity finance and stock markets, Stiglitz (1993) is of the view that equity from stock markets have a distinct advantage from the perspective of entrepreneurs in that risk is shared with the provider of capital and there is no fixed obligation for repaying the funds; and that from the social point of view, as risks are shared between the entrepreneur and the capital provider, the firm will not normally cut back production as much as it would with debt finance, if there is a downturn in the economy. The report by World Federation of Exchanges (2017) also states that in providing investors with access to a range of investment opportunities, stock markets enable investors (through diversification) to reduce their risk of income volatility by diversifying their investment portfolios and a comparatively easy means of exiting their investment in that the shares listed on a stock exchange can be sold in the secondary market. This, together with positive investment returns enhances opportunities for investors, thereby generating further funds to finance growth and expansion. From the perspective of investors, the main objective is creation of shareholder value in the form of dividends and capital gain, which in some instances may stand in conflict with interests of company executives according to the 'agency theory' and can be addressed through proper corporate governance actions by devising executives performance management and remuneration strategy aligned with shareholders' interests (Bender \& Ward, 2009).

Nevertheless, Stiglitz (1993) is hesitant about the potential of raising much capital through issuing equities in developing countries. He is of the opinion that the existence of well-organized secondary markets for securities and the standard accounting procedures enforced by taxing and regulatory authorities make equities attractive by increasing liquidity, allowing easy portfolio diversification and reducing managerial malpractices to protect investors; which are, however, not available in most less developed countries making hopes of raising substantial amounts of capital in this form less reasonable in the context of these countries.

The general empirical consensus according to the World Bank Independent Evaluation Group (2016) report, however, is that as the economy grows, countries' demand for stock markets services increases more than the demand for services provided by banks. This is taken as a justification for the dominance of bank-based structures in the early stages of growth, while the relative importance of bank services decrease as economies develop. Alexander (2017) on Working Paper Series of European Central Bank (ECB) also shared the broad conclusion by empirical researches on the real effects of financial structure that the marginal contribution of banks to economic growth declines while that of capital markets increases with economic development, primarily due to capital market financing is better at promoting innovation and productivity, and at financing new sources of growth rather than bank-based system.

This general consensus described above, that bank-based finance is better in early stages of growth and that the need for market-based equity finance increases as economy develops, is consistent with the existing bank-based financial services policy in Ethiopia in the context of the early growth stage of the economy.

\subsection{Analysis of Conditions in Ethiopia}

The accessibility of debt finance from banks in Ethiopia is very limited as we can observe from different surveys and reports. According to the survey result by Mulu Gebreeyesus et al. (2018), more than $70 \%$ of micro and small enterprises had no access to credit from any of the potential sources; thus, they had to rely on their own 
funds; and from the enterprises that had access to loans, Micro Finance Institutions (MFIs) seem to be the main source for both investment and working capital with two-thirds of these enterprises reported having loan access from MFIs, and only about 15\% from formal banks. Regarding private sector access to bank credit as a source of finance in Ethiopia, the analysis by International Financial Corporation (2019) shows that only 16.4 percent of the private sector used finance from banks for its activities, compared with Kenya and Uganda, which used about 41 and 21 percent respectively; and that private sector credit amounted to only 9 percent of Gross Domestic Product in Ethiopia, in contrast to the 20 percent median for Sub-Saharan Africa.

From global financial information source, The Findex Database 2017 (Demirgüç-Kunt et al., 2018) indicates that borrowing from financial institutions to start, operate, or expand a farm or business (percentage of age 15+) is very low, only 11\% in 2017 with some improvement from 7\% in 2014. Doing Business 2019 Indicators for getting credit also shows that Ethiopia stands on a very bad position scoring only 15 out of 100 points and with a rank of 175 out of 198 countries, remaining far behind comparator neighboring economies (Rwanda sores $95 \%$ with a rank 3, Kenya scores $90 \%$ with a rank 8, Egypt scores $65 \%$ with a rank 60).

With increasing financial inclusion due to growing financial literacy and expanding bank branches, the saving culture of Ethiopians is improving as witnessed by The Global Findex Database 2017 (Demirgüç-Kunt et al, 2018) that shows the percentage of people age 15+ that saved in any way reached $62 \%$ in 2017 from $48 \%$ in 2014. However, this global financial database also indicates formal saving in the financial institutions was very low although it had shown significant increment from 11\% in 2014 to $26 \%$ in $2017 ; 38 \%$ is in semi-formal form or saving using savings clubs; and the remaining $36 \%$ is saving in other form which includes simply saving in cash at home "under the mattress" or saving in the form of livestock, jewelry, or real estate.

These evidences put together signify that credit access from banks for the development of business is a serious problem in the country and finding an alternative or complementing businesses development financing means seems a matter calling for urgent attention. Establishing a vibrant stock market in the country would attract the channeling of savings from the unbanked groups and semi-formal savings to the formal financial system. From the knowledge of the saving culture of the people and as supported by the global financial database, savings in the form of large numbers of cattle ownership, grains storage, and a high tendency to acquire land and houses in urban centers are common forms of savings, with the expectation of appreciation of value with time rather than putting in productive and job creating investments. In this context, the establishment and development stock market in Ethiopia is a viable alternative and complementary mechanism to banking sector for the mobilization of the huge untapped savings in the semi-formal and informal form to support the investment and growth of businesses in the country.

\subsection{Stock Market Functioning, Institutions and Regulatory Frameworks}

A stock market is an organized market place licensed by a relevant regulatory body, where ownership stakes (shares) in companies are listed and traded. Vibrant stock markets allow individuals and institutions to invest in businesses, helping allocate capital where it is needed and supporting efforts to innovate. Through the efficient allocation of capital, these markets allow companies to invest in growth and develop new products and services, leading to increased employment opportunities and wealth creation.

For companies to have access to capital, investors must be willing to supply capital. According to the United States Treasury report on Capital Markets (2017), however, without robust investor protections that underpin confidence in the markets, such as the predictable and consistently applied rule of law and the enforceability of contracts, investors may be less willing to provide capital. This calls for a well-designed regulatory structure, one that promotes fairness, predictability, and efficiency for investors and companies alike, which are crucial to healthy capital markets.

According to a White Paper by World Economic Forum (2016), establishing capital markets is a long, drawn-out process because it requires step-by-step establishment of financial instruments, regulatory and legal frameworks, market infrastructure, and the establishment of a critical mass of market participants. The World Federation of Exchanges (2017) also state that the activities in both the primary and secondary markets occur within a framework of laws, rules and regulations, aimed at ensuring the existence of fair, transparent and orderly markets. The rules and regulations of the markets will primarily have the responsibility to protect the assets of the investors, guarantee transparency of the process for transferring ownership of shares, lay down the requirements for listing and companies that are listed on markets must comply, and provide clear processes for the settlement of disputes when arise.

As a matter of fact, on primary markets issuers of new stocks sell them to investors via an underwriting process; whereas, in secondary markets existing securities are sold and bought among investors or traders, on an 
exchange, or on over-the-counter markets, sometimes intermediated by brokers or primary dealers. Through the initial listings and ongoing disclosure requirements, stock markets reduce the costs of information search by the investors to make the investment decisions, which help address the 'information asymmetry' problem where company insiders have more information about the company than outsiders.

The United States Treasury report (2017) asserts that secondary markets facilitate investment opportunities for individuals and companies to establish market-based valuations, which help investors allocate capital efficiently and provide liquidity for entrepreneurs, workers, and investors who wish to cash out all or part of their investments. According to European Union High Level Forum on the Capital Markets Union (2020), broader economic benefits accrue from the price discovery process that public trading in the secondary market makes the overall allocation of capital more efficient, facilitates the funding of innovation and, ultimately, permit the economy to settle on a higher growth trajectory.

Stock markets provide trading flatforms where trading on stocks happens based on pre-set transparent public rules and that information about the prices at which investors are willing to buy and sell, and the prices at which instruments have been sold (pre- and post-trade transparency) are publicly available (World Federation of Exchanges, 2017). According to the Report to Congress by Division of Economic and Risk Analysis of the United States Securities and Exchange Commission/SEC (2017), for example, the United States securities laws require that all offers and sales of securities be either registered with the SEC under the Securities Act of 1933 (the Securities Act) or conducted under an exemption from registration in the same act. This report also contains that a registered offer is accompanied by extensive disclosure process at the time of the offering and subsequent reporting, whereas capital raising through transactions exempt from registration allow issuers to avoid certain regulatory burdens and the increased oversight that comes with a registered offering generally subject to investor restrictions and/or offering limits due to less information disclosure and less oversight.

World Economic Forum (2016) and New Zealand Council of Financial Regulators (2018) stipulate strong and stable regulatory and legal framework and robust corporate governance standards that are fundamental for providing market participants with the confidence to enter the stock market. It is also stated that the frameworks and standards should supply clear legal guidance on how business is conducted and what happens in cases of bankruptcy; and provide clarity on accounting standards, disclosures and other reporting requirements to address the problem of information asymmetry which could allow financial service providers and company insiders to extract excessive profits.

In light of the above discussions, the establishment of well-functioning stock market requires strong regulatory and legal frameworks with the ability to create level playing field for the actors in the market which include investors, issuers, intermediaries and payments settlement service providers. Ethiopia as a country with no stock market and with a need to establish this market as discussed in section 1 and 2 above, should embark on coordinated actions focusing on at least the following three aspects of the stock market: transparency and market confidence, diversified investor base, and financial literacy of issuers and investors to promote market participation (World Economic Forum, 2016). Concerning transparency and market confidence, there are some reform initiatives of the Government of Ethiopia in the financial and legal systems. As a case in point, we can take the phased implementation of International Financial Reporting Standards (IFRS) based on the Financial Reporting Proclamation No. 847/2014 of Ethiopia and Regulation No. 332/2014 where the first phase adoption was for Significant Public Interest Entities (Financial Institutions and Public Enterprises); the second phase was for Other Public Interest Entities; and the third phase for adoption of the IFRS for small and medium enterprises.

Diversifying and broadening the investor base should be taken as the second important aspect of stock market development in Ethiopia. The limited long-term investment opportunity for institutional investors, with the only option of buying government securities at negative rates of return putting them at risk of losing the value of their investment and jeopardizing the capacity of meeting future pension obligations of pension funds subscribers particularly (International Finance Corporation, 2019). Therefore, the development of stock market in the country widens investment opportunity for potential institutional investors which may include Government Employees Social Security Fund, Private Employees Social Security Fund, Community Health Insurance Fund, Conventional Insurance Companies, Cooperatives Unions, Public Enterprises, and private companies and for individual retail investors. As the Ethiopian economy has been growing at a faster rate (World Bank Ethiopia Economic Update, 2018; National Bank of Ethiopia Annual Report, 2018/19; International Financial Corporation, 2019), the establishment of properly functioning stock market can attract the growing savings in the hands of the entities mentioned above for investment in productive sectors of the economy. To enhance the liquidity in the stock market, further diversification of the investor base is needed to realistically look for potential investors even out of the economy of the country. Such possibilities provide grounds for bigger stock markets with lots of 
trading activity assuring more liquidity for market participants than thinner markets with limited trading opportunities (Odunga \& Ayoyi, 2016). In this regard, the two potential areas which need serious consideration are attracting and encouraging remittances of the wide Ethiopian diaspora (International Financial Corporation, 2019) and integrating to regional stock markets in Eastern Africa by allowing cross border listing in the countries of the region (IFC, 2019; and Odunga \& Ayoyi, 2016). Ethiopia's policy of pursuing a more active approach to regional economic integration through the Common Market for Eastern and Southern Africa (COMESA), the Intergovernmental Authority on Development (IGAD), and greater stability in the Horn of Africa, enhanced by the recent peace agreement between Ethiopia and Eritrea will further increase the size and attractiveness of the stock market in Ethiopia (IFC, 2019).

As Ethiopian investors and companies do not have exposure to a functioning stock market, the third aspect, financial literacy is very important. According to World Economic Forum (2016), both the potential issuers and potential investors must understand the issuance process and how financial markets function and the risk-return profile associated with specific stocks offer, otherwise investors are more likely to suffer unanticipated losses and lose confidence in stock markets. The government and concerned private bodies, hence, should give due consideration to the financial literacy aspect when moving ahead to establish the stock market.

\section{Conclusion and Recommendations}

The Ethiopian economy has been growing at a faster rate for more than the last fifteen years. The main source of growth of the economy has been largely the strong public investment in infrastructure and public services, whereas the capability for the production of goods and services for domestic use and export has been lagging behind the expectations, exposing the economy to the problems of high unemployment, inflation and foreign exchange shortage. The economy has also been characterized by weak private sector performance due to insufficient access to financial resources as the credit market in the country has been overwhelmingly dominated by state-owned banks whose lending efforts have been dedicated to expanding public infrastructure projects and state owned enterprises.

The 'Home-grown Economic Reform' initiative of the government has aimed at reducing expansionary fiscal policy is expected to bring some adjustments in the financial resources allocation policy so that the Ethiopian financial system mainly functioning through bank intermediation so far gives proper attention to the private sector by considering the introduction of market-based financial resources access options as an alternative and complementary to bank based system so that the private sector can have better choice for its long term investment needs. The establishment and development of stock market is regarded as one major viable option in this respect.

To determine the appropriateness of having a stock market at this stage of Ethiopian economy, review of literature and detailed analysis of selected models was carried out. The literature on theoretical discussions and empirical findings had shown the proposition that there was a positive correlation between stock market development and economic growth had huge support. The review had also shown that the stock markets provided competitive and complementary services to bank finance, encouraging banks to increase their efficiency, and allowing households and firms to better manage risks associated with long-term investments. There were also significant number of empirical works which supported a positive relationship between stock market and economic growth in Africa.

Two models analyzed to determine whether the recommendation to establish a stock market is feasible or not, 'business growth life cycle' model and the financial structure model, resulted in consistent and complementing findings. Because of the high business risk during the startup and early growth stage, according to 'business growth life cycle' model, the recommendation for the economy like Ethiopian was to get risk-free own finance or low risk equity finance to keep the financial risk at lower level.

Based on the financial structure model, on the other hand, the general consensus was that for less developed countries bank-based finance was better in their early stages of growth and that the need for market-based equity finance increased as the economy developed and also that the marginal contribution of banks to economic growth declined while that of capital markets increased with economic development. In the context of the early growth stage of the Ethiopian economy, based on this model, the effort of the government to expand bank credit services was considered as an advisable option as growth finance mechanism. However, the accessibility of debt finance from banks in Ethiopia had been skewed to public projects and that private sector access had been very limited. As a way of addressing this problem the establishment and development stock market in Ethiopia would be a viable alternative and complementary mechanism to banking sector for the mobilization of the huge untapped savings held in the semi-formal and informal form to support the investment and growth of businesses 
in the country.

Based on the main findings summarized above, the following recommendations can be drawn for policy consideration in the stock market development process.

1) Given the Ethiopian economy at early stage of growth, business enterprises outside small holder agriculture are largely thought to be at growth stage and many more new start-ups are expected to be added to sustain the growth. Based on enterprises growth life cycle model, financial access to enterprises in this situation requires equity finance which is facilitated through stock markets in the market based financial system. Although bank finance is a preferred way of financing early growth in less developed countries like Ethiopia based on the financial structure model, banks credit access especially to the private sector is found to be insufficient and the banking system could not attract significant amount of savings held in form of semi-formal and informal savings in the community. Therefore, establishing and developing stock market in Ethiopia is strongly recommended to complement bank services and as an alternative financial access system both to investors and entrepreneurs.

2) We have seen that enhanced liquidity facilitates investment in longer-run, higher-return projects that boost productivity growth. We have also seen that in Africa stock market development and economic growth is positively responsive to stock market turnover (measure of liquidity) rather than stock market capitalization and stock value traded. To enhance the liquidity of the stock market to be established, broad-based and diversified investor and issuer base with wider trading activity is recommended, which should include

a. Government Employees Social Security Fund, Private Employees Social Security Fund, Community Health Insurance Fund, Cooperatives Unions, Public Enterprises, and private companies and individual retail investors (focusing on those whose savings are in semi-formal and informal form);

b. attracting and encouraging the participation of Ethiopian diaspora; and

c. In the medium and longer term, integrating to regional stock markets in Eastern Africa by allowing a cross border listing in the countries of the region.

3) Developing a stock market requires the establishment of strong regulatory and legal frameworks, efficient market infrastructure, and the establishment of a critical mass of market participants, aimed at ensuring the existence of fair, transparent and orderly markets. The government and concerned private sector bodies should work together to adequately fulfill these conditions for the successful stock market establishment.

4) As both potential investors and issuing companies in Ethiopia do not have exposure to a functioning stock market, the government and concerned private sector bodies, hence, should give due consideration to the financial literacy aspect when moving ahead to establish the stock market.

\section{Acknowledgements}

The author would like to thank Berhanu Kuma (PhD), Associate Professor of Agricultural Economics at Wolayta Soddo University for his guidance and comments on the initial draft of this paper.

\section{References}

Abenet, B. (2018). Local Capital Market: Better Late than Never. Fortune, 19(948).

Admasu, S. (2017). Productive Capacity and Economic Growth in Ethiopia.

African Development Bank. (2018). African Economic Outlook 2018.

Agbélénko, F. A. (2016). Stock Market Development and Long-Run Economic growth in Africa. International Journal of Research in Finance and Marketing (IJRFM), 6(8), 19-30.

Ali, A. S. (2016). The Viability of Establishing Capital Market in Developing Countries: The Case of Ethiopia. https://doi.org/10.2139/ssrn.3522964

Ayyagari, M. et al. (2012). Financing of Firms in Developing Countries. https://doi.org/10.1596/1813-9450-6036

Bandopadhyaya, A. et al. (2012). Corporate Financial Strategy.

Bender, R., \& Ward, K. (2009). Corporate Financial Strategy (3rd ed.). https://doi.org/10.4324/9780080942841

Biau, C. (2018). Common Capital Market Infrastructure for East Africa. Options for the Way Forward

Boubakari, A., \& Jin, D. (2010). The Role of Stock Market Development in Economic Growth: Evidence from Some Euronext Countries. International Journal of Financial Research, 1(1). https://doi.org/10.5430/ijfr.v1n1p14 
Demirgüç-Kunt, A. et al. (2018). The Global Findex Database 2017. Measuring Financial Inclusion and the Fintech Revolution, The World Bank. https://doi.org/10.1596/978-1-4648-1259-0

Emmanuel, A. S., \& King, S. (2014). Effect of Capital Market Development on Economic Growth in Ghana. European Scientific Journal, 10(7).

ENA. (2019). Ethiopia Introduces New Economic Reform to Rectify Macroeconomic Imbalance. News, August 29, 2019.

IFC, World Bank Group. (2019). Creating Markets in Ethiopia: Sustaining Progress Towards Industrialization.

Ikikii, S. M., \& Nzomoi, J. N. (2013). An Analysis of the Effects of Stock Market Development on Economic Growth in Kenya. International Journal of Economics and Finance, 5(11). https://doi.org/10.5539/ijef.v5n11p145

Levine, R., \& Zervos, S. (1998). Stock Markets, Banks, and Economic Growth. The American Economic Review, $88(3), 537-558$.

Mulu, G. et al. (2018). Main Features of Micro and Small Manufacturing Enterprises in Ethiopia. Baseline Survey Report.

National Bank of Ethiopia. (2019). 2018/19 Annual Report.

Odunga, R., \& Ayoyi, I. R. (2016). Impact of Financial Markets on the Economic Growth of East Africa. European Journal of Logistics, Purchasing and Supply Chain Management, 4(5), 25-33.

Popov, A. (2017). Evidence on finance and economic growth. ECB Working Paper Series.

Ruecker, R. (2011). Market Potential Assessment and Road Map Development for the Establishment of Capital Market in Ethiopia.

Schiereck, D. et al. (2018). Public Corporations in Africa - A Continental Survey on Stock Exchanges and Capital Markets Performance. The Jena Economic Research Papers.

Solomon, G. (2019). Should Ethiopia Promote the Development of a Stock Exchange Market? Capital News Paper.

Stiglitz, J. E. (1993). Financial Markets and Development. Oxford Review of Economic Policy, 5(4). https://doi.org/10.1093/oxrep/5.4.55

Tirole, J. (2006). The Theory of Corporate Finance.

Tiruneh, L. (2012). Establishing financial markets in Ethiopia: The environmental foundation, challenges and opportunities. JBAS, 4(1).

Torre, A., \& Schmukler, S. L. (2007). Emerging Capital Markets and Globalization.

World Bank Group. (2019). Doing Business.

World Bank, IEG. (2016). The World Bank Group's Support to Capital Market Development.

World Bank. (2018). THE Inescapable Manufacturing-Services Nexus: Exploring the potential of distribution services. Ethiopia Economic Update.

World Economic Forum. (2016). Accelerating Capital Markets Development in Emerging Economies: Country Case Studies.

World Federation of Exchanges. (2017). The Role of Stock Exchanges in Fostering Economic Growth and Sustainable Development.

\section{Copyrights}

Copyright for this article is retained by the author(s), with first publication rights granted to the journal.

This is an open-access article distributed under the terms and conditions of the Creative Commons Attribution license (http://creativecommons.org/licenses/by/4.0/). 